Original Research Article

\title{
Performance, Antimicrobial Effect and Carcass Parameters of Finisher Broilers Given Xylopia aethiopica Dried Fruits (Grains of Selim) as Additive
}

\author{
Jonathan Ogagaoghene Isikwenu, Ifeanyi Udeh, Bernard Izuchukwu Oshai, Theresa Ogheneremu Kekeke
}

Department of Animal Science, Delta State University, Asaba Campus, Nigeria

\begin{abstract}
The effect of graded levels of grains of selim on the performance, gut microbial population and carcass characteristics of finisher broilers was investigated. Two hundred and four (204) 28 days old broiler chicks (Marshal breed) were randomly allotted to four treatments with each treatment having three replicates of 17 chicks each in a completely randomized design. Finely blended grains of selim was administered through drinking water on treatments 2,3 and 4 at concentrations of $0.5,0.7$ and $0.9 \mathrm{~g}$ per litre while chicks on treatment 1 (control) received $1.0 \mathrm{~g}$ per 1.5 litre of antibiotics (Gendox). Chicks were fed ad libitum with isonitrogenous and isocaloric diets containing $20 \%$ crude protein and $3000 \mathrm{Kcal} / \mathrm{kg}$ metabolisable energy for four weeks. Results showed no significant $(P>0.05)$ differences among treatments in the final body weight, total weight gain, daily weight gain, total feed intake, daily feed intake and feed:gain ratio. There were differences in the microbial population of the gastro-intestinal tract with colony count decreasing as the concentration of grains of selim increases. Carcass characteristics and organ weights were similar $(P>0.05)$ except for thigh and spleen weights, and large intestine lengths where differences $(P<0.05)$ exist. Mortality ranged from $8.47 \%-13.47 \%$ across treatments. The results indicated that grains of selim have antimicrobial and anthelminthic properties, and promote growth in broiler chickens.
\end{abstract}

Keywords: anthelminthic; antibiotics; antimicrobial; grains of selim (Xylopia aethiopica dried fruits); growth promoter; residual effects; resistant.

\section{INTRODUCTION}

Xylopia aethiopica is an evergreen aromatic tree growing up to $20 \mathrm{~m}$ high and belonging to the order Magnoliales and family Annonaceae. It is native to the low land forests and moist fringe forests in the Savanna zones of Africa. The dried fruits of Xylopia aethiopica (grains of selim) are used as a spice and an herbal medicine. There is increasing reluctance in relying on therapeutic solutions in animal health using drugs, due to long and intensive use of antibiotics in animal husbandry that have resulted in bacteria that are resistant to most antibiotics in hospitals (Ziggers, 2012). Consumers are becoming more conscious and concerned about the residual effect of antibiotics in poultry products.

In the light of these reports on residual effects there is now increased interest in poultry production to do without using antibiotics and other drugs (Hossain, 2009). It is becoming evident that in raising animals for food, a more nutritionbased health strategy must play a major role in future development of animal production (Hossain, 2009). Some herbs, spices and extracts have been found to stimulate feed intake and endogenous secretions or possess antimicrobial, coccidiostatic or anthelminthic activities (Hossain, 2009; Karimi et al., 2010). Several types of herbal products and their extracts have enhanced broiler performance and resulted in growth-promoting effects (Karimi et al., 2010). They opined that these herbal products may serve as an environmental friendly alternatives to the antibiotic growth promoters commonly used in animal and poultry feed. Their growth-promoting ability is attributed to their antimicrobial properties, oxidative-resistant activity, enhancement of the immune system and consequently improvement in poultry performance. The increasing price of antibiotics and other drugs in addition to the residual effects of use has created the need for research into nutrition-based natural products that are as effective and cheaper than antibiotics as other therapeutic drugs. We hypothetised that grains of selim affect performance and health status of broilers. Therefore this study is designed to investigate the effect of grains of selim (Xylopia aethiopica dried fruits) on broiler chicken performance.

\section{MATERIALS AND METHODS}

\section{Experimental site}

The experiment was carried out at the Poultry Research Unit of the Department of Animal Science, Delta State University, Asaba Campus, Nigeria.

\section{Experimental birds and management}

A total of two hundred and four (204) 28 days old broiler chicks (Marshal Breed) weighing from 974-1089 g were used in this study. The birds were managed in a deep litter house of twelve pens with dimensions of $2.04 \mathrm{~m} \times 2.03 \mathrm{~m}$ during the 
finishing phase. Feed and water were provided ad libitum while necessary prophylaxis and vaccinations were administered.

\section{Experimental design}

The broiler chicks were randomly allotted into four treatment groups with three replicates on equal weight basis in a completely randomized design. Each treatment group consisted of 51 broiler chicks and 17 in each replicate.

\section{Experimental diets}

Birds were fed the same isonitrogenous and isocaloric diet containing 20\% crude protein and $3000 \mathrm{Kcal} / \mathrm{kg}$ metabolisable energy. Finely blended powder of grains of selim was obtained by pulverising with mortar and pestle, milling with homogenizer and passed through a standard $2 \mathrm{~mm}$ sieve to remove fibre. Weights of $0.5,0.7$ and $0.9 \mathrm{~g}$ of grains of selim were dissolved in a litre of water each for more than 8 hours and administered to chicks in treatment 2, 3 and 4 in their drinking water, while chicks in treatment 1 (Control) were given antibiotics in their water ( $1.0 \mathrm{~g}$ per 1.5 litre of water). Powder of grains of selim is soluble in water and the amount needed in grams is too small to be mixed into feed. Antibiotics and grains of selim were administered for 5 days in drinking water. The proximate composition of Xylopia aethiopica dried fruits is presented in Table 1. The phytochemical composition of Xylopia aethiopica is presented in Table 2. The composition of the finisher broiler chick diets are presented in Table 3.

Table 1. Proximate compositions of Xylopia aethiopica (Fruits)

\begin{tabular}{|lc|}
\hline Parameters (\%) & \\
\hline Moisture & $16.04 \pm 1.25$ \\
Total ash & $4.37 \pm 0.85$ \\
Crude fibre & $12.14 \pm 0.70$ \\
Total fat & $9.55 \pm 2.10$ \\
Crude protein & $2.10 \pm 0.25$ \\
Total carbohydrate & $55.80 \pm 4.26$ \\
Calcium & $0.193 \pm 0.021$ \\
Phosphorus & $0.620 \pm 0.04$ \\
\hline
\end{tabular}

Abolaji et al. (2007)

Table 2. Phytochemical constituents of Xylopia aethiopica dried fruits (grains of selim)

\begin{tabular}{|lc|}
\hline Phytochemical Tests & Results \\
\hline Alkaloids & ++ \\
Flavonoids & +++ \\
Tannins & ++++ \\
Steroids & ++ \\
Saponin & + \\
\hline
\end{tabular}

$+=$ Slightly present

$++=$ Moderately present

$+++=$ Present

$++++=$ Strongly present

\section{Measurements}

Body weight development (measured by weighing birds weekly), body weight gain, feed intake and mortality were recorded on replicate basis weekly and feed:gain ratio was calculated according to Lambert et al. (1936). Faecal samples were collected from each replicate for microbial identification and population count after administering grains of selim and antibiotics. All fresh droppings were collected in each replicate pen before dawn and thoroughly mixed. Faecal samples were collected on the $7^{\text {th }}$ day after 5 days of administering antibiotics and grains of selim. One gram of the wet faecal samples from each replicate were emulsified in a drop of normal saline on a microscopic slide and covered with a cover slip. The samples were then examined with $\times 10$ objective lens and the organisms found were identified with $\times 40$ objective lens. One $g$ of the wet faecal samples was also inoculated into peptone water and incubated for 8 hours at $37^{\circ} \mathrm{C}$. The solution was then subcultured with a wire loop into Desoxycholate Citrate Agar (DCA) and MacConkey plates and incubated at 37 ${ }^{\circ} \mathrm{C}$ for 24 hours. Isolates from culture were biochemically identified using lactose, indole, urease, oxidase, citrate, manitol, glucose, sucrose and coagulase reagents.

At the end of eight weeks (56 days), two birds per replicate group, fasted overnight were weighed and slaughtered by cutting the jugular vein for carcass measurements. Moreover, organs weighed included heart, liver, pancreas, spleen and gizzard. The length of intestines was measured as well and the colon, small intestine, large intestine and caeca lengths were expressed in $\mathrm{cm}$ per $100 \mathrm{~g}$ dressed weight.

\section{Phytochemical screening}

Phytochemical screening for major constituents was done using methods (spectrophotometry, precipitation and emulsion formation) as described by Trease and Evans (1989) and Sofowora (1993) for the presence of alkaloids, flavonoids, tannins, steroids and saponin (Table 2).

\section{Chemical analysis}

The chemical analysis of the proximate composition of the experimental diet (Table 3 ) was determined according to the procedure of AOAC (1990).

\section{Statistical analysis}

Data collected were subjected to analysis of variance and treatment means were compared by Duncan's Multiple Range Test (Duncan, 1955) using SPSS (16.0) package.

\section{RESULTS}

The effect of graded levels of grains of selim on the body weight development of finisher broilers is presented 
Table 3. Composition of experimental finisher broiler diet

\begin{tabular}{|c|c|c|c|c|}
\hline \multirow[b]{2}{*}{ Parameters } & \multicolumn{4}{|c|}{ Treatments } \\
\hline & $\begin{array}{c}* 1 \\
(1 \mathrm{~g} / 1.5 \text { litre })\end{array}$ & $\begin{array}{c}* * 2 \\
(0.5 \mathrm{~g} / \text { /itre })\end{array}$ & $\begin{array}{c}* * 3 \\
(0.7 \mathrm{~g} / \text { litre })\end{array}$ & $\begin{array}{c}* * 4 \\
(0.9 \mathrm{~g} / \text { litre })\end{array}$ \\
\hline Maize (Yellow) & 58.20 & 58.20 & 58.20 & 58.20 \\
\hline Groundnut cake & 24.20 & 24.20 & 24.20 & 24.20 \\
\hline Wheat offal & 6.60 & 6.60 & 6.60 & 6.60 \\
\hline Fish meal & 4.50 & 4.50 & 4.50 & 4.50 \\
\hline Limestone & 1.50 & 1.50 & 1.50 & 1.50 \\
\hline Bone meal & 3.50 & 3.50 & 3.50 & 3.50 \\
\hline Premix (finisher) ${ }^{1}$ & 0.50 & 0.50 & 0.50 & 0.50 \\
\hline Salt & 0.50 & 0.50 & 0.50 & 0.50 \\
\hline Methionine & 0.30 & 0.30 & 0.30 & 0.30 \\
\hline Lysine & 0.20 & 0.20 & 0.20 & 0.20 \\
\hline Total & 100.00 & 100.00 & 100.00 & 100.00 \\
\hline \multicolumn{5}{|l|}{ Calculated Analysis } \\
\hline Crude Protein (\%) & 20.09 & 20.09 & 20.09 & 20.09 \\
\hline Crude fibre $(\%)$ & 3.38 & 3.38 & 3.38 & 3.38 \\
\hline Calcium (\%) & 1.81 & 1.81 & 1.81 & 1.81 \\
\hline Phosphorus (\%) & 0.92 & 0.92 & 0.92 & 0.92 \\
\hline Metabolizable Energy (Kcal/kg) & 3000.00 & 3000.00 & 3000.00 & 3000.00 \\
\hline \multicolumn{5}{|l|}{ Determined Analysis } \\
\hline$\overline{\text { Dry matter }(\%)}$ & 82.00 & 82.00 & 82.00 & 82.00 \\
\hline Crude protein $(\%)$ & 20.50 & 20.50 & 20.50 & 20.50 \\
\hline Crude fibre (\%) & 5.74 & 5.74 & 5.74 & 5.74 \\
\hline Ether extract $(\%)$ & 15.09 & 15.09 & 15.09 & 15.09 \\
\hline $\operatorname{Ash}(\%)$ & 10.21 & 10.21 & 10.21 & 10.21 \\
\hline NFE (\%) & 30.46 & 30.46 & 30.46 & 30.46 \\
\hline
\end{tabular}

${ }^{1}$ Each $2.5 \mathrm{~kg}$ vitamin-mineral premix provided the following: A 8,000,000 iu, $\mathrm{D}_{3} 2,000,000 \mathrm{iu}, \mathrm{E} 5000 \mathrm{mg}, \mathrm{K}_{3} 2000 \mathrm{mg}$, Folic acid 500 $\mathrm{mg}$, Niacin 15,000mg, Calpan 5,000 mg, B $8000 \mathrm{mg}, \mathrm{B}_{12} 10,000 \mathrm{mg}, \mathrm{B}_{1} 1,500 \mathrm{mg}, \mathrm{B}_{6} 1,500 \mathrm{mg}$, Biotin $20 \mathrm{mg}$, Antioxidant 1,250 mg. *Antibiotic (Gendox:100 mg gentamycin and $50 \mathrm{mg}$ deoxycycline cyclate) **Grains of selim

Table 4. Performance characteristics of broiler finisher birds fed different concentrations of grains of selim (Xylopia aethiopica dried fruits)

\begin{tabular}{|c|c|c|c|c|c|}
\hline \multirow[b]{2}{*}{ Parameters } & \multicolumn{5}{|c|}{ Treatments } \\
\hline & $\begin{array}{c}* 1 \\
(1 \mathrm{~g} / 1.5 \text { litre })\end{array}$ & $\begin{array}{c}* * 2 \\
(0.5 \mathrm{~g} / \text { litre })\end{array}$ & $\begin{array}{c}* * 3 \\
(0.7 \text { g/litre })\end{array}$ & $\begin{array}{c}* * 4 \\
(0.9 \mathrm{~g} / \text { litre })\end{array}$ & SEM \\
\hline Initial Body wt (g) & 974.00 & 1065.00 & 1040.00 & 1089.00 & 21.56 \\
\hline Final Body wt (g) & 2074.00 & 2006.00 & 1984.00 & 2172.70 & 33.87 \\
\hline Total Weight Gain (g) & 1100.00 & 941.00 & 944.00 & 1083.70 & 43.60 \\
\hline Daily Weight Gain (g) & 39.29 & 33.61 & 33.71 & 38.70 & 1.56 \\
\hline Total Feed Intake (g) & 3747.00 & 3697.60 & 3801.00 & 4043.50 & 72.50 \\
\hline Daily Feed Intake (g) & 133.82 & 132.06 & 135.75 & 144.41 & 2.61 \\
\hline Feed: Gain Ratio & 3.41 & 3.93 & 4.03 & 3.73 & 0.20 \\
\hline Mortality (\%) & 12.50 & 13.47 & 8.50 & 8.47 & 1.20 \\
\hline
\end{tabular}

a, $b$ means with different superscripts in the same row are significantly $(P<0.05)$ different. SEM: Standard Error of the Mean* Antibiotic (Gendox: $100 \mathrm{mg}$ gentamycin and $50 \mathrm{mg}$ deoxycyline cyclate)**Grains of selim

in Table 4. The final mean body weight, total weight gain, daily weight gain, total feed intake, daily feed intake and feed : gain ratio of broilers in all treatments were similar $(P>0.05)$. Mortality was due to coccidiosis and was high in treatments 1 and 2 (antibiotics and $0.5 \mathrm{~g} /$ litre grains of selim) but slightly lower in treatments 3 and 4 with $0.7 \mathrm{~g}$ and $0.9 \mathrm{~g}$ grains of selim per litre of water.

The results of the microscopy and colony count of 
Table 5. Microscopy and colony count of microorganisms of finisher broiler faeces fed different concentrations of grains of selim (Xylopia aethiopica dried fruits)

\begin{tabular}{|c|c|c|c|c|}
\hline \multirow[b]{2}{*}{ Parameters } & \multicolumn{4}{|c|}{ Treatments } \\
\hline & $\begin{array}{c}* 1 \\
(1 \mathrm{~g} / 1.5 \text { litre })\end{array}$ & $\begin{array}{c}* * 2 \\
(0.5 \mathrm{~g} / \text { /itre })\end{array}$ & $\begin{array}{c}* * 3 \\
(0.7 g / \text { /itre })\end{array}$ & $\begin{array}{c}* * 4 \\
(0.9 \mathrm{~g} / \text { litre })\end{array}$ \\
\hline Microscopy & Ascaridia spp. (6) & $\begin{array}{l}\text { No ova, } \\
\text { Cyst or protozoan }\end{array}$ & $\begin{array}{l}\text { No ova, } \\
\text { Cyst or protozoan }\end{array}$ & $\begin{array}{c}\text { No ova, } \\
\text { Cyst or protozoan }\end{array}$ \\
\hline $\begin{array}{l}\text { Colony count } \\
(\text { E. coli })\end{array}$ & $10^{7}$ organisms $/ \mathrm{ml}$ & $10^{5}$ organisms $/ \mathrm{ml}$ & $10^{3}$ organisms $/ \mathrm{ml}$ & 10 organisms $/ \mathrm{ml}$ \\
\hline
\end{tabular}

* Antibiotic (Gendox: $100 \mathrm{mg}$ gentamycin and $50 \mathrm{mg}$ deoxycyline cyclate) **Grains of selim

Table 6. Carcass quality characteristics of finisher broilers fed different concentrations of grains of selim (Xylopia aethiopic dried fruits)

\begin{tabular}{|c|c|c|c|c|c|}
\hline \multirow[b]{2}{*}{ Parameters } & \multicolumn{5}{|c|}{ Treatments } \\
\hline & $\begin{array}{c}* 1 \\
(1 \mathrm{~g} / 1.5 \text { litre })\end{array}$ & $\begin{array}{c}* * 2 \\
(0.5 \mathrm{~g} / \text { litre })\end{array}$ & $\begin{array}{c}* * 3 \\
(0.7 \mathrm{~g} / \text { litre })\end{array}$ & $\begin{array}{c}* * 4 \\
(0.9 \mathrm{~g} / \text { litre })\end{array}$ & SEM \\
\hline Live weight (kg) & 2.35 & 2.12 & 2.47 & 2.50 & 0.67 \\
\hline Plucked weight (kg) & 2.19 & 1.97 & 2.31 & 2.30 & 0.59 \\
\hline Eviscerated weight $(\mathrm{kg})$ & 1.84 & 1.66 & 1.94 & 1.91 & 0.51 \\
\hline Dressed weight (kg) & 1.75 & 1.54 & 1.77 & 1.74 & 0.44 \\
\hline Head weight $(\mathrm{kg})$ & 0.05 & 0.06 & 0.05 & 0.05 & 0.00 \\
\hline Shank weight (kg) & 0.07 & 0.06 & 0.08 & 0.08 & 0.01 \\
\hline Drum stick weight (kg) & 0.26 & 0.22 & 0.26 & 0.24 & 0.01 \\
\hline Breast weight $(\mathrm{kg})^{1}$ & 0.43 & 0.39 & 0.48 & 0.45 & 0.02 \\
\hline Back weight $(\mathrm{kg})^{1}$ & 0.37 & 0.38 & 0.40 & 0.43 & 0.02 \\
\hline Neck weight $(\mathrm{kg})^{1}$ & 0.17 & 0.11 & 0.11 & 0.08 & 0.02 \\
\hline Thigh weight $(\mathrm{kg})^{1}$ & $0.30^{\mathrm{a}}$ & $0.25^{\mathrm{b}}$ & $0.33^{\mathrm{a}}$ & $0.27^{\mathrm{ab}}$ & 0.01 \\
\hline Wing weight $(\mathrm{kg})^{1}$ & 0.19 & 0.16 & 0.22 & 0.17 & 0.01 \\
\hline
\end{tabular}

a, $b$ means with different superscripts in the same row are significantly $(P<0.05)$ different. SEM: Standard Error of the Mean * Antibiotic (Gendox: $100 \mathrm{mg}$ gentamycin and $50 \mathrm{mg}$ deoxycyline cyclate) ${ }^{* *}$ Grains of selim ${ }^{1}$ Percentage of eviscerated weight

Table 7. Organ weights of finisher broilers fed different concentrations of grains of selim (Xylopia aethiopica dried fruits)

\begin{tabular}{|c|c|c|c|c|c|}
\hline \multirow[b]{2}{*}{ Parameters } & \multicolumn{5}{|c|}{ Treatments } \\
\hline & $\begin{array}{c}* 1 \\
(1 \mathrm{~g} / 1.5 \text { litre })\end{array}$ & $\begin{array}{c}* * 2 \\
(0.5 \mathrm{~g} / \text { litre })\end{array}$ & $\begin{array}{c}* * 3 \\
(0.7 \mathrm{~g} / \text { litre })\end{array}$ & $\begin{array}{c}* * 4 \\
(0.9 \mathrm{~g} / \text { litre })\end{array}$ & SEM \\
\hline Heart weight (g) & 10.21 & 11.07 & 10.98 & 12.40 & 0.38 \\
\hline Liver weight (g) & 41.40 & 48.25 & 52.68 & 43.03 & 2.99 \\
\hline Pancreas weight (g) & 3.65 & 4.30 & 4.75 & 3.98 & 0.26 \\
\hline Spleen weight (g) & $4.47^{\mathrm{a}}$ & $2.80^{\mathrm{b}}$ & $2.92^{\mathrm{b}}$ & $3.98^{\mathrm{ab}}$ & 0.27 \\
\hline Gizzard (without lining) (g) & 41.21 & 44.57 & 44.58 & 39.87 & 1.13 \\
\hline Colon $(\mathrm{cm} / 100 \mathrm{~g} \mathrm{DW})$ & $0.71^{\mathrm{c}}$ & $1.01^{\mathrm{a}}$ & $0.97^{\mathrm{b}}$ & $1.00^{\mathrm{a}}$ & 0.04 \\
\hline Small Int.(cm/100g DW) & $6.67^{\mathrm{d}}$ & $7.90^{\mathrm{a}}$ & $7.24^{\mathrm{c}}$ & $7.42^{\mathrm{b}}$ & 0.13 \\
\hline Large Int.(cm/100g DW) & $5.86^{\mathrm{a}}$ & $5.81^{\mathrm{b}}$ & $5.19^{\mathrm{d}}$ & $5.41^{\mathrm{c}}$ & 0.08 \\
\hline Proventriculus $(\mathrm{cm} / 100 \mathrm{~g} \mathrm{DW})$ & 0.26 & 0.26 & 0.26 & 0.28 & 0.00 \\
\hline Caeca $(\mathrm{cm} / 100 \mathrm{~g}$ DW) & $2.17^{\mathrm{c}}$ & $2.70^{\mathrm{a}}$ & $2.39^{b}$ & $2.62^{\mathrm{a}}$ & 0.06 \\
\hline
\end{tabular}

a, $\mathrm{b}$ means with different superscripts in the same row are significantly $(P<0.05)$ different. SEM: Standard Error of the Mean DW: Dressed weight. Int: Intestine. * Antibiotic (Gendox: $100 \mathrm{mg}$ gentamycin and $50 \mathrm{mg}$ deoxycyline cyclate) $\quad * *$ grains of selim 
microorganisms in finisher broiler faeces are presented in Table 5. The results showed the presence of six (6) Ascaridia spp. in treatment I (control) given antibiotic while none was found in treatments 2, 3 and 4 given grains of selim. Treatment 1 had the highest population of Escherichia coli (E. coli) $\left(10^{7}\right.$ organisms per $\left.\mathrm{ml}\right)$ count which progressively decreased as the concentration of grains of selim increased in the drinking water of treatments $2\left(10^{5} \mathrm{org} / \mathrm{ml}\right), 3\left(10^{3}\right.$ $\mathrm{org} / \mathrm{ml})$ and $4\left(10^{1} \mathrm{org} / \mathrm{ml}\right)$, respectively. The results of the carcass quality characteristics and organ weights are presented in Tables 6 and 7. There were no significant $(P>$ $0.05)$ differences in any carcass parameters in the treatment groups except for the thigh weight that was significantly $(P<0.05)$ lower in treatment 2 than treatments 1 and 3 . Most organ weights, heart, liver, pancreas and gizzard were similar $(P>0.05)$ except for the spleen weight which was significantly $(P<0.05)$ lower in treatment 2 and 3 than treatment 1 .

The colon, small intestine, large intestine and caeca lengths (expressed in cm per $100 \mathrm{~g}$ dressed weight) of the treatment groups were significantly $(P<0.05)$ different. The proventriculus length also expressed in $\mathrm{cm}$ per $100 \mathrm{~g}$ dressed weight was similar $(P>0.05)$ for all the treatment groups.

\section{DISCUSSION}

The similarities in the final body weights, total weight gain, daily weight gain, total feed intake, daily feed intake and feed:gain ratio in Table 4 is an indication that finisher broilers in all treatment groups responded equally in weight development to the diet and additives supplied. The weight development pattern also shows that tissue synthesis proceeded at the same rate between broilers given antibiotic and grains of selim as additives. This result indicates that grains of selim do have growth promoting potentials just like antibiotics and therefore can be used as a natural alternative to replace synthetic growth-promoting antibiotics in finisher broiler production. The weight performance improvement in this study is in tandem with the results of Tekeli et al. (2011), Herawati (2010), Onu (2010), Javed et al. (2009) and Farinu et al. (2004) who reported improved body weight gain in broilers when ginger (Zingiber officinale, a spice) was used at different rates in feed or drinking water as an additive. Al-Mashadani et al. (2011), Mansoub (2011), Toghyani et al. (2010), Al-Kassie (2009), Bolukbasi et al. (2006) and Zhang et al. (2005) used also thyme as an additive in broiler production and found improved body weight performance and concluded that thyme oil or powder may be a promising alternative to antibiotic growth promoters. Toghyani et al. (2010) stated that thyme powder increased body weight gain in broiler chicks compared to control and this effect was almost the same as in the antibiotic-treated (flavophospholipol) birds. Mansoub (2011), Aji et al. (2011), Kumar et al. (2010) and Pourali et al. (2010) also stated that the use of garlic (powder or aqueous extract) as an additive in broiler production produced improved body weight gain, daily feed intake and feed conversion ratio. Al-Kassie et al. (2011), Lee et al. (2010) and Gowda et al. (2009), all reported improved body weight gain and feed conversion ratio when turmeric (Curcuma longa) powder was used at different rates as a feed supplement. The similarities in feed intake and feed:gain ratio which conform to the growth pattern in this study also agree with the reports of these authors. The improved performance of grains of selim may be attributed to the presence of several compounds in the fruits (flavoniods, sterols, saponins, tannins, phlobatannins and cyanogenetic glycosides) which have biological activities such as antioxidant, antimicrobial and pharmacological effects (Ilusanya et al., 2012; Ezekwesili et al., 2012). The alkaloids, flavonoids and steroids obtained from the screening of grains of selim in this study have been found to be antimicrobial substances against a wide array of microorganisms in vitro (Yadav and Munin, 2011).

The absence of Ascaridia spp. in the treatments with grains of selim shows that it possesses some anthelminthic activities and therefore, seems to be lethal to Ascaridia spp. The progressive decrease of microbial population and colony count as the concentration of grains of selim increased in the treatments also indicates that grains of selim has antimicrobial activities. The dominant micro-organism identified in the population was Escherichia coli, and the reduction in its population with increased concentration of grains of selim shows that grains of selim has components possessing antibacterial activities. This result agrees with the findings of Rahimi et al. (2011) who reported that a $0.1 \%$ dose of thyme reduced E. coli and improved lactic acid bacterial populations in the gut of broilers and that of Sudrashan et al. (2010) who obtained significant reduction in the bacterial counts of Staphylococcus, E. coli and Salmonella spp. when essential oil isolated from ginger was used as a decontaminating agent in chicken meat. The carcass quality characteristics of the treatment groups were all similar because the body weight gains of broiler chicks were similar and since carcass is the outcome of body weight development, it agrees with body weight improvement pattern obtained from the treatment groups. Broiler chickens given graded levels of grains of selim performed as well as those on antibiotics in all the carcass parameters measured. Although, the thigh weight of treatment 2 was lower than that of treatment 1 and 3 , it did not cancel the fact that grains of selim have the same growth promoting capability as antibiotics. The results of this study agree with the previous reports of Zhang et al. (2009) and Javed et al. (2009) who obtained improved carcass quality output when broiler chicks were given ginger as a feed additive. 
The organ measurements of heart, liver, pancreas and gizzard followed the same pattern as the carcass parameters. Although, the spleen weight and colon caeca, small intestine and large intestine lengths (expressed as $\mathrm{cm}$ per $100 \mathrm{~g}$ dressed weight) showed differences, these variables did not follow any definite trend. They did not affect the fact that grains of selim have growth promoting potentials similar to antibiotics growth promoters.

\section{CONCLUSION}

The similarity of the weight performance, the reduction effect on specific pathogenic microbial population in the intestine and the similarity of carcass and organ measurements of finisher broilers in this study indicate that Xylopia aethiopica dried fruits (grains of selim) has growth promoting potentials and can serve as a natural alternative to antibiotics in broiler production. It possesses anthelminthic activitives (it is lethal to Ascaridia spp.). However, more work needs to be done to standardise the effective doses and determine the separate roles played by the dried fruits pulp and seeds in its growth promoting activities.

\section{REFERENCES}

Abolaji O. A., Adebayo A. H., Odesanmi O. S. (2007): Nutritional qualities of three medicinal plant parts (Xylopia aethiopica, Blighia sapida and Parinari polyandra) commonly used by pregnant women in the western part of Nigeria. Pakistan Journal of Nutrition 6 (6): 665-668.

Aji S.B., Ignatius K., Ado A. Y., Nuhu J.B., Abdulkarim A. (2011): Effects of feeding onion (Allium cepa) and garlic (Allium sativum) on some performance characteristics of broiler chickens. Research Journal of Poultry Science 4: 22-27.

Al-Kassie G.A.M. (2009): Influence of two plants extracts derived from thyme and cinnamon on broiler performance. Pakistan Veterinary Journal 29: 169-173.

Al-Kassie G.A.M., Mohseen A.M., Abd-Al-Jaleel R.A. (2011): Modification of productive performance and physiological aspects of broilers on addition of a mixture of cumin and turmeric to the diet. Research Opinions in Animal \& Veterinary Sciences 1: 31-34.

Al-Mashhadani E.A., Farah K.A., Farhan Y.M., Al-Mashhadani H.E. (2011): Effects of anise, thyme essential oils and their mixture on broiler performance and some on physiological traits. Egyptians Poultry Science 31: 481-489.

AOAC (1990): Official Methods of Analysis. Association of Official Analytical Chemists $15^{\text {th }}$ edition. Washington, D.C.
Bolukbasi S.C., Erhan M.K., Ozkan A. (2006): Effects of dietary thyme oil and vitamin E on growth, lipid oxidation, meat fatty acid composition and serum lipoproteins of broilers. South African Journal of Animal Science 36: 189-196.

Duncan D.B. (1955): Multiple range and Multiple F-tests. Biometrics 11: 1-42.

Ezekwesili C.N., Nwodo O.F.C., Eneh F.U., Ogbunugafor H. A. (2010): Investigation of the chemical composition and biological activity of Xylopia aethiopica Dunal (Annonacae). African Journal of Biotechnology 9(43): 7352-7356.

Farinu G.O., Ademola S.G., Ajayi A.O., Babatunde G. M. (2004): Growth, haematological and biochemical studies on garlic and ginger-fed broiler chickens. Moor Journal of Agriculture Research 5: 122-128.

Gowda N.K.S., Ledoux D.R., George E.R., Bermudez A.J., Chen Y. C. (2009): Antioxidant efficacy of Curcuminoids from turmeric (Curcuma longa L.) powder in broiler chickens fed diets containing aflatoxin B1. British Journal of Nutrition 102: 1629-1634.

Herawati (2010): The effect of feeding red ginger as phytobiotic on body weight gain, feed conversion and internal organs condition of broiler. International Journal of Poultry Science 9(10): 963-967.

Hossain M.M. (2009): Herbs versus drugs: Aspect of World Poultry. Engonormix.com/./165/po.htm

Ilusanya O.A.F., Odunbaku O.A., Adesetan T.O., Amosun O.T. (2012): Antimicrobial activity of fruit extracts of Xylopia aethiopica and its combination with antibiotics against clinical bacterial pathogens. Journal of Biology, Agriculture and Healthcare 2 (9): 1-9.

Javed M., Durrani F., Hafeez A., Khan R.U., Ahmad I. (2009): Effect of aqueous extract of plant mixture on carcass quality of broiler chicks. ARPN Journal of Agricultural and Biological Science 4: 37-40.

Karimi A., Yan F., Coto C., Park J.H., Min Y., Lu C., Gidden J. A., Lay J.O., Waldroup P.W. (2010): Effects of level and source of oregano leaf in starter diets for broiler chicks. Journal of Applied Poultry Research 19(2): 137-145.

Kumar S., Sharadmma K.C., Radhakrishna (2010): Effect of garlic active based growth promoter on growth performance and specific pathogenic intestinal microbial counts of broiler chicks. International Journal of Poultry Science 9: 244- 246.

Lambert W.V., Elis N.R., Block W.H., Titus H.W. (1936): The role of nutrition in genetic research. The American Society of Animal Production 29: 236.

Lee S.H., Lillehoj H.S., Jang S.I., Kim D.K., Ionescu C., Bravo D. (2010): Effect of dietary Curcuma, Capsicum and Lentinus on enhancing local immunity against Eimeria acervulina infection. Journal of Poultry Science 47: 89-95. 
Mansoub N.H. (2011): Comparison of effects of using thyme and probiotic on performance and serum composition of broiler chickens. Advances in Environmental Biology 5: 2012-2015.

Onu P.N. (2010): Evaluation of two herb spices as feed additives for finisher broilers. Biotechnology in Animal Husbandry 26: 383-392.

Pourali M., Mirghelenj S.A., Kermanshahi D. (2010): Effect of garlic powder on productive performance and immune response of broiler chickens challenged with Newcastle disease virus. Global Veterinaria 4: 616 - 621.

Rahimi S., Teymouri Zadeh Z., Karimi Torshizi M.A., Omidbaigi R., Rokni H. (2011): Effect of three herbal extracts on growth performance, immune system, blood factors and intestinal selected bacterial population in broiler chickens. Journal of Agriculture Science Technology 13: 527-539.

Sofowora A. (1993): Medicinal plants and traditional medicine in Africa. Spectrum Books Ltd., Ibadan Nigeria, $289 \mathrm{p}$.

SPSS 16.0 Statistical Package for the Social Sciences. SPSS Inc. Chicago, IL, 60606.

Sudrashan S., Fairoze N., Wildfred S., Shekar R. (2010): Effect of aqueous extract and essential oils of ginger and garlic as immunostimulant in chicken meat. Research Journal of Poultry Science 3: 58-61.

Tekeli A., Kutlu H.R., Celik L. (2011): Effect of Z. officinale and propalis extracts on the performance, carcass and some blood parameters of broiler chicks. Current Research in Poultry Science 1: 12-23.

Toghyani M., Tohidi M., Gheisari A.I., Tabeidian S.A. (2010): Performance, immunity, serum biochemical and haematological parameters in broiler chick fed dietary thyme as alternative for an antibiotic growth promoter. African Journal of Biotechnology 9: 6819-6825.

Trease G.E., Evans W.C. (1989): Textbook on Pharmacognosy, $12^{\text {th }}$ ed. Baillière and Tindall, London.

Yadav R.N.S., Munin A. (2011): Phytochemical analysis of some medicinal plants. Journal of Phytology. 3 (12): 1014.

Zhang G.F., Yang Z.B., Wang Y., Yang W.R., Jiang S.Z., Gai G.S. (2009): Effects of ginger root (Zingiber officinale) processed to different particle sizes on growth performance, antioxidant status and serum metabolites of broiler chickens. Poultry Science 88: 2159- 2166.

Zhang K., Yan Y.F., Keen C.A., Waldroup P.W. (2005): Evaluation of microencapsulated essential oils and organic acids in diets for broiler chickens. International Journal of Poultry Science 4: 612-619.

Ziggers D. (2012): Antibiotics will kill us. All About Feed 20(1): 5

Received: July 22, 2014

Accepted after revisions: December 15, 2014

\section{Corresponding author:}

\section{J.O. Isikwenu}

Department of Animal Science

Delta State University

Asaba Campus, Nigeria

E-mail: jisikwenu@yahoo.com 